\title{
TEKHNIK NON FARMAKOLOGI MOBILISASI DINI PADA NYERI POST SC
}

\author{
Retty Nirmala Santiasari*, Lina Mahayati ${ }^{* *}$, Anggraini Dwita Sari*** \\ ${ }^{1,2,3}$ STIKes William Booth Surabaya, JL. Cimanuk No.20 Surabaya. \\ E-mail: rettynirmala@gmail.com
}

\begin{abstract}
ABSTRAK
Sectio caesarea adalah proses persalinan yang tidak melewati jalan lahir melainkan proses buatan pegeluaran janin melalui tinndakan pembedahan abdomen. Proses pembedahan abdomen menimbulkan luka dan memberikan dampak bagi ibu, dampak yang paling dirasakan adalah nyeri akut. Apabila nyeri pada ibu post section caesarea tidak teratasi dapat menyebabkan berbagai masalah diantaranya terjadi limfopeni, leukositosis, takikardi, pernafasan menjadi dangkal, memperlambat involusi uteri, dan mempersulit pemberian ASI. Tujuan dari study kasus ini adalah memberikan asuhan keperawatan pasien dengan diagnosa medis post section caesarea dan masalah keperawatan nyeri akut di Ruang Mawar Merah RSUD Bangil Kabupaten Pasuruan. Metode ini adalah study kasus dengan sampel 2 pasien post section caesarea yang dirawat selama 3 hari. Sehinga study kasus didapatkan diagnose prioritas nyeri akut. Implementasi yang dilakukan pada kedua klien adalah mengidentifikasi lokasi, karakteristik, durasi, frekuensi, kualitas dan intensitas nyeri, memberikan posisi nyaman pada pasien, memeberikan terapi tekhnik relaksasi dan distraksi: mobilisasi bertahap, memberikan terapi analgesic sesuai advis dokter. Teknik distraksi adalah Teknik pengalihan rasa nyeri pasien dengan cara mengalihkan perhatiannya, bahkan meningkatkan toleransi terhadap nyeri. Tekhnik distraksi mobilisasi dini yaitu latihan gerak sendi, gaya berjalan, toleransi aktivitas sesuai dengan kemampuan dan kesejajaran tubuh. Evaluasi pada pasien 1 dan 2 dengan masalah keperawatan nyeri akut yaitu didapatkan pasien mengatakan nyeri berkurang. Hasil menunjukkan keefektifan implementasi mobilisasi dini terhdap rasa nyeri pasien.
\end{abstract}

Kata Kunci : Mobilisasi Dini , Nyeri Akut, Post section caesarea

\begin{abstract}
Sectio caesarea is a place of artificial labor where the fetus needs help through an incision in the stomach. Incision wounds have an impact on the mother and the most felt impact is acute pain. If the pain in post SC mothers cannot overcome the problems caused by lymphopenia, leukocytosis, tachycardia, breathing becomes shallow, improves uterine involution, and complicates breast milk replacement. The purpose of this case study is to carry out nursing care for patients by diagnosing SC medical posts and acute nursing problems in the Mawar Merah Room of Bangil District Hospital in Pasuruan Regency. This method is a case study with a sample of 2 post SC patients who were treated for 3 days. So that the case study obtained a diagnosis of acute painful priority. Implementation of the second client is location placement, characteristics, duration, frequency, quality and tension, providing comfort to the patient,
\end{abstract}


providing relaxation therapy, gradual mobilization, observing TTV, handling, $T F U$, operating wounds and location, providing analgesic therapy according to doctor's advice. . The technique diverts the client's attention to something else so that it can reduce alertness to safety, even increase the increase in pain. The technique plays early mobilization about exercise, gait, and regulates activities according to the abilities and alignment of the body. Evaluation of patients 1 and 2 with acute pain nursing problems obtained by patients said the disease was reduced. The results show the effectiveness of the implementation of early mobilization with regard to patient pain.

Keywords: SC Post, Acute Pain, Early Mobilization.

\section{PENDAHULUAN}

Persalinan adalah suatu proses pengeluaran hasil konsepsi (janin) yang dapat bertahan hidup ke dunia luar, dari rahim melalui jalan lahir atau jalan lain (Rustam, 2011). Ada tiga jenis proses persalinan yaitu persalinan spontan atau fisiologis, persalinan bantuan dan persalinan anjuran dengan tindakan seperti sectio caesarea (Manuaba, I, 2010). Section caesarea merupakan suatu tindakan pembedahan untuk mengeluarkan janin dengan cara membuka dinding perut dan dinding uterus (Wiknjosastri, 2006). Tindakan operasi sectio caesarea menyebabkan nyeri dan mengakibatkan terjadinya terputusnya kontinuitas jaringan. Nyeri yang dialami dapat menimbulkan berbagai masalah, salah satunya dapat mempengaruhi terhadap masalah laktasi. Menurut
Julianti, 2014 bahwa 68\% ibu post sectio caesarea mengalami kesulitan dengan perawatan bayi, bergerak naik turun dari tempat tidur dan mengatur posisi yang nyaman selama menyusui akibat adanya nyeri.

Data Word Health Organitation (WHO) pada tahun 2016 yang didapatkan adalah tingkat persalinan dengan metode SC menjadi meningkat $10 \%-15 \%$ sejak 30 tahun yang lalu, fenomena ini terjadi di negara-negara berkembang (Sherly\&Erina, 2016). Sedangkan hasil Riskesdas 2018 menjelaskan bahwa angka kejadian ibu melahirkan di Indonesia sebanyak $79 \%$ dimana hal tesebut $15 \%$ ibu melahirkan di RS pemerintah dan $18 \%$ di RS. Swasta dengan metode operasi SC.

Manajemen nyeri yang dilakukan pada pasien dengan post section caesarea adalah dengan memberikan 
Tindakan farmakologi berupa analgesik. Upaya pemberian Tindakan farmakologi merupakan tindakan yang bertujuan untuk mengatasi rasa nyeri sesaat, dan tidak dapat mengontrol rasa nyeri, bahkan pemberian analgesik dapat meningkatkan toleransi rasa nyeri yang dialami. Sedangkan tindakan non farmakologi dapat membantu menurunkan rasa atau sensasi nyeri dan rasa tersebut dapat membantu proses pemulihan yang tidak menimbulkan efek samping berbahaya.

Salah satu terapi nonfarmakologi yang digunakan untuk mengurangi nyeri post SC adalah mobilisiasi dini. Mobilisasi dini direkomendasikan pada ibu post SC karena selain dapat menurunkan nyeri juga dapat meningkatkan kemandirian pasien post SC dan membantu proses pemulihan luka.

Mobilisasi dini post $S C$ adalah suatu kegiatan aktivitas ibu atau adanya aktivitas yang dilakukan ibu segera setelah proses persalinan SC. Latihan mobilisasi bertujuan untuk membuat pasien dapat berkonsentrasi atau memfokuskan pikiran pada gerakan yang dilakukan dibandingkan pada rasa nyeri yang dialami (Potter \& Perry, 2006). Hal ini memicu adanya pengeluarann hormone norepinefrin dan serotonin. Pelepasan senyawa ini dapat merangsang sistem kontrol desenden. Di dalam sistem kontrol desenden terdapat dua substansi yang dapat mempengaruhi proses pengontrolan rasa nyeri, yaitu yang pertama adalah adanya pelepasan substansi $\mathrm{P}$ oleh neuron delta-A dan delta-C. Hal kedua yaitu dengan adanya mekanoreseptor dan neuron beta-A yang menstimulasi neurotransmitter sebagai penghambat opiat endogen seperti endorfin dan dinorfin. Hal ini menjadi lebih dominan untuk menutup atau mencegah mekanisme pertahanan dan menghambat substansi P. Proses ini memberikan efek pada substansi $P$ dalam menurunkan transmisi saraf menuju saraf pusat sehingga menurunkan persepsi nyeri (Smeltzer \& Bare, 2002). Menurut penelitian Dirgahayu Inggrid (2019) menyatakan bahwa terdapat pengaruh mobilisasi dini terhadap tingkat nyeri pada pasien post sectio caesarea.

Kegiatan penelitian ini menggunakan data yang didapatkan 
dari hasil praktik ners di RSUD Bangil, Kabupaten Pasuruan di ruang Mawar dari 24 pasien yang dirawat di ruangan terdapat 14 pasien yang melakukan tindakan SC dimana 3 pasien dilakuan tindakan SC karena pre eklamsi, 5 pasien dilakukan tindakan SC karena pembukaan jalan lahir yang lama, dan 6 pasien dilakukan tindakan SC karena ketuban pecah dini. Hal ini menunjukkan bahwa nyeri akut pada pasien dengan post SC sering dijumpai di ruangan. Di ruangan sering dijumpai ibu yang mengalami post SC sulit untuk melakukan mobilisasi dini karena nyerinya bertambah saat bergerak, bahkan terdapat pasien yang sampai mengalami masalah laktasi dikarenakan takut mobilisasi dan menyusui. Sehingga peneliti tertarik untuk meneliti penurunan nyeri melalui tekhnik non farmakologi mobilisasi dini pada pasien post sc di RSUD Bangil Kabupaten Pasuruan.

\section{METODE}

Desain penelitian yang digunakan adalah studi kasus. Studi kasus merupakan bentuk eksplorasi suatu fenomena dengan adanya batasan terperinci, proses pengambilan data yang mendalam yang didukung dari berbagai sumber informasi. Dalam penelitian studi kasus ini bertujuan untuk mengeksplorasi asuhan keperawatan pada pasien yang mengalami Post SC dengan masalah keperawatan nyeri akut di ruang Mawar Merah RSUD Bangil Kabupaten Pasuruan dengan menggunakan alat ukur skala nyeri Numeric Rating scale untuk menilai skala nyeri yang dirasakan pasien menggunakan angka-angka untuk menggambarkan range dari intensitas nyeri dengan kriteria nilai 0 tidak nyeri, 1-3 nyeri ringan, 4-6 nyeri sedang, dan 7-10 nyeri berat. Lama waktu perawatan pasien yaitu 3 hari. Pengumpulan data dilakukan dengan observasi dan pemeriksaan fisik. Disamping integritas penelitian (instrumen utama menggunakan lembar observasi), uji validitas data dilakukan dengan cara melakukan intervensi pada pasien yang mempunyai karakteristik yang sama dengan memperpanjang waktu pengamatan/tindakan dan sumber informasi tambahan menggunakan tiga sumber data yaitu pasien, perawat dan keluarga pasien yang berkaitan dengan masalah yang 
diteliti. Pada penelitian ini, peneliti menegakkan pada masalah etika penelitian dimana lembar persetujuan diberikan sebelum penelitian dilaksanakan kepada objek yang akan diteliti maka harus menandatangani lembar persetujuan, tetapi apabila subjek menolak maka peneliti tidak memakai dan menghormati haknya sebagai subjek.

\section{HASIL}

Hasil penelitian menunjukkan kedua repsonden berusia remaja akhir dan dewasa awal dalam rentang usia 20-35 tahun dengan kehamilan primigravida maupun multigravida. Pada pasien 1 dan 2 didapatkan hasil pengkajian nyeri PQRST (P: luka post SC, Q: disayat-sayat, R: perut bagian bawah, S: skala 4 dari 0-10 skala NRS, T: nyeri muncul saat bergerak/beraktivitas. Sedangkan pada pasien 2 didapatkan hasil pengkajian nyeri PQRST (P: luka post SC, Q: disayat-sayat, R: perut bagian bawah, S: skala 5 dari 0-10 skala NRS, T: nyeri muncul saat bergerak/beraktivitas. Pada pasien post SC mengalami masalah nyeri akut karena pada pasien yang mengalami persalinan secara SC akan melalui proses pembedahan yang menyebabkan terputusnya kontinuitas jaringan pada area luka insisi yang mengakibatkan pelepasan mediator nyeri (bradykinin, histamin, dan prostaglandin) sehingga merangsang pusat nyeri.

\section{PEMBAHASAN}

Pengkajian pada pasien pertama dan kedua dengan nyeri post SC saat dikaji pasien mengatakan nyeri pada area luka operasinya, pasien nampak meringis kesakitan. Gejala dan tanda nyeri menurut PPNI (2016) pasien mengeluh nyeri, pasien tampak meringis kesakitan, frekuensi nadi meningkat, sulit tidur, bersikap protektif (misalya waspada, posisi menghindari nyeri). Dari penjabaran diatas dapat dilihat bahwa terdapat kesenjangan pada karakterisitik antara teori dan kasus nyata yaitu pasien 1 dan 2 tidak mengalami peningkatan frekuensi nadi. Pada pasien 1 tidak terjadi peningkatan frekuensi nadi karena pasien pernah mengalami persalinan sebelumnya dan memiliki pengalaman nyeri sehingga pasien mampu beradaptasi dengan rasa nyeri yang dialaminya. Sedangkan pada pasien 2, pasien 
memiliki system pendukung yang mampu membuat pasien mudah beradaptasi dengan rasa nyeri yang dialami. Saat pasien 2 menagalami nyeri, suami pasien mengajari pasien untuk melakukan relaksasi napas dalam sehingga pasien dapat mentolerir rasa nyeri yang dialami.

Berdasarkan data diagnosa keperawatan yang ditemukan pada pasien pertama dan kedua yaitu nyeri akut, risiko infeksi dan menyusi tidak efektif. Secara teori diagnosa keperawatan yang muncul adalah nyeri akut berhubungan dengan terputusnya kontinuitas jaringan sekunder akibat pembedahan, risiko infeksi berhubungan dengan peningkatan perentanan tubuh terhadap bakteri sekunder pembedahan, hambatan mobilitas fisik berhubungan dengan kelamahan fisik, defisit perawatan diri berhubungan dengan immobilisasi, gangguan pola tidur. Pada kasus nyata dan teori ditemukan kesenjangan yaitu dimana pada kasus nyata ditemukan diagnose menyusui tidak efektif. Menurut Hillan (1992) dalam Anggorowati, dkk 2007 menyebutkan bahwa sebanyak $68 \%$ ibu post sc mengalami kesulitan dalam melakukan perawatan bayi, melakukan aktivitas untuk bergerak naik turun dari tempat tidur, bahkan kesulitan mengatur posisi yang nyaman selama memberikan ASI disebabkan adanya rasa nyeri. Rasa nyeri yang dirasakan ibu dapat menyebabkan ibu menunda pemberian ASI sejak awal pada bayinya. Rasa nyeri yang dirasakan ibu timbul karena selama proses menyusui ibu mengalami peningkatan intensitas nyeri pada bekas luka yang ditimbulkan akibat aktivitas ibu. (Batubara dkk, 2008). Pada kasus nyata tidak diangkat masalah gangguan mobilitas fisik karena pada intervensi nyeri yang diberikan yaitu mobilisasi dini selain dapat meningkatkan toleransi nyeri pasien, mobilisasi dini juga dapat meningkatkan kemandirian pasien untuk beraktivitas. Hal ini didukung oleh hasil penelitian Dwi Tina $\mathrm{R}$ (2017) yang berjudul "Asuhan Keperawatan Dengan Penerapan Mobilisasi Dini Untuk Meningkatkan Kemandirian Pasien Post Sc Di Ruang Bougenvil Rsud Kebumen" bahwa asuhan keperawtan dengan mobilisasi dini pada pasien post SC efektif 
meningkatkan kemandirian pasien. Pada kasus nyata tidak diangkat masalah deficit perawatan diri karena perawatan diri pasien terpenuhi dengan dibantu oleh keluarga dan perawat. Pasien juga dalam tahap mobilisasi dini, jika mobilisasi dini pasien dapat terlampaui maka pasien dapat melakukan perawatan dirinya secara mandiri. Pada kasus nyata tidak diangkat masalah gangguan pola tidur karena pada pasien tidak ditemukan tanda gejala pasien kurang tidur, pasien mengatakan tidurnya tercukupi.

Rencana asuhan keperawatan dalam pemberian mobilisasi dini dilakukan dengan beberapa tahap yaitu 6 jam perrtama pasien dianjurkan untuk relaksasi napas dalam dan melakukan Gerakan abduksi dan adduksi pada kaki dan tangan. Pada 6-10 jam berikutnya pasien dianjurkan untuk miring kanan dan miring kiri. Pada 24 jam berikutnya pasien dianjurkan untuk berlatih duduk, jika tidak ada keluhan pasien dianjurkan untuk duduk di sisi tempat tidur, jika duduk disisi tempat tidur tidak ada keluhan pasien dianjurkan untuk berlatih berdiri lalu berjalan.
Implementasi pada pasien oertama dan kedua tidak terdapat kesenjangan. Pada implementasi pasien 1 dan pasien 2 terfokus menggunakan tindakan mobilisasi dini. Tindakan mobilisasi dini dilakukan dengan beberapa tahap yaitu 6 jam pertama post operasi SC pasien dianjurkan untuk melakukan tekhnik napas dalam dan menggerakkan kaki dan tangan, selanjutnya 6-10 jam berikutnya pasien dianjurkan untuk melakukan miring kanan dan miring kiri, 24 jam post op SC pasien dianjurkan untuk duduk atau posisi semi fowler, jika dirasa tidak ada keluhan selama duduk atau berada dalam posisi semi fowler pasien diperbolehkan untuk duduk dengan perlahan menurunkan kaki ke lantai, dan jika tidak ada keluhan pasien diperbolehkan untuk belajar berdiri dan berjalan diskitar tempat tidur pasien. Intervensi mobilisasi dini pada diagnose nyeri merupakan salah satu intervensi tekhnik nonfarmakologi yaitu tekhnik distraksi . Menurut hasil penelitian Inggrid Dirgahayu (2019) mengatakan bahwa tindakan terapi non farmakologis mobilisasi dini berpengaruh pada tingkat nyeri pada 
pasien post SC . Mobilisasi dini merupakan upaya yang dapat dilakuka sebagai proses pegalihan rasa nyeri dengan mengalihkan konsentrasi ibu pada luka bekas operasi sc. Mobilisasi dini juga dapat mengurangi aktivasi mediator kimiawi pada proses peradangan yang mampu meningkatkan respons nyeri serta mengurangi proses transmisi saraf nyeri menuju saraf pusat. Melalui mekanisme tersebut, mobilisasi dini efektif dalam menurunkan intensitas nyeri pascaoperasi (Nugroho, 2010).

Evaluasi keperawatan yang didapatkan setelah dilakukan tindakan keperawatan mobilisasi dini selama 3 hari yaitu pasien 1 dan pasien 2 didapatkan masalah teratasi ditandai dengan pasien mengatakan nyeri berkurang, pasien tampak rileks, dan pasien mampu bergerak meskipun terasa nyeri.

Maka dapat disimpulkan bahwa mobilisasi dini dapat menurunkan skala nyeri pada masalah nyeri akut post SC. Hasil penelitian ini dapat dijadikan pertimbangan dasar atau bahan data penelitian selanjutnya dengan cara dan teknik yang berbeda serta faktor- faktor lain yang berhubungan dengan nyeri akut pada post SC.

\section{KESIMPULAN}

Dari hasil yang didapatkan setelah penulis memberikan intervensi mobilisasi dini pada masalah nyeri akut post SC didapatkan pasien pertama dan kedua mengalami penurunan skala nyeri dari skala nyeri 6 menjadi skala nyeri 2, pasien dapat beraktifitas. Maka dapat disimpulkan bahwa mobilisasi dini dapat menurunkan skala nyeri dan meningkatkan toleransi terhadap nyeri pada masalah nyeri akut post SC

\section{DAFTAR PUSTAKA}

Anggorowati, Nuzulia, F. 2007 . Hubungan antara Dukungan Keluarga dengan pemberian ASI Eksklusif pada bayi di desa Bebengan Kecamatan Boja Kabupaten Kendal . Jurnal Ilmiah Departemen Keperawatan Maternitas dan Anak, Jurusan Keperawatan Fakultas Kedokteran Universitas Diponegoro Semarang.

A Potter, \& Perry, A. G. (2006) Buku Ajar Fundamental Keperawatan: Konsep, Proses, Dan Praktik, edisi 4, Volume.2. Jakarta: EGC

Inggrid Dirgahayu.(2019). Pengaruh Mobilisasi Dini terhadap Tingkat 
Nyeri pada Pasien Post Sectio Cesarea di RSUD Al-Ihsan Kab. Bandung.

http://doi.org/10.22216/jen.v2i2. 1852. Diakses pada tanggal 21 Juni 2020

Kementrian Kesehatan RI. 2018. Riset Kesehatan Dasar. Jakarta: Kemenkes RI. Diakses pada tanggal 22 Juli 2020 dari http://www.depkes.go.id/resource

Batubara, P. L. 2008. Farmakologi Dasar, edisi II. Jakarta:Lembaga Studi dan Konsultasi Farmakologi.

Dwi Tina R.(2017). Asuhan Keperawatan Dengan Penerapan Mobilisasi Dini Untuk Meningkatkan Kemandirian Pasien Post Sc Di Ruang Bougenvile Rsud Kebumen. http://eprints.poltekkesjogja.ac.id /2041/13/lamp\%204.\%20SOP.pd f._Diakses pada tanggal 8 Juli 2020

Nugroho, Taufan. 2010. Buku Ajar Ginekologi. Yogyakarta: Nuha Medika

Sherly Erina Lidia Widia (2019) Hubungan Antara Teknik Pernafasan Dalam Dengan Skala Nyeri Ibu Post Sectio Caesaria 24 Jam Pertama Di Rsud Dr. H. Andi Abdurahman Noor Tanah Bumbu. Diakses pada tanggal 27 Juni 2020 dari http://www.jurnalkesehatan.id/index.php/JDAB/a rticle/download/22/21/ s/download/infoterkini/materi_ra korpop_20

18/Hasil\%20Riskesdas\%202018. pdf

Manuba.2010.Ilmu

Kandungan

Penyakit

KB.Jakarta:EGC dan

Mochtar, Rustam. 2011. Sinopsis Obstetri. Jakarta: EGC

Smeltzer, Suzanne C. dan Bare, Brenda G, 2002, Buku Ajar Keperawatan Medikal Bedah Brunner dan Suddarth (Ed.8, Vol.1,2) Alih Bahasa oleh Agung Waluyo, dkk. Jakarta: EGC

Wiknjosastro, H. 2006. Ilmu Kebidanan. Jakarta : EGC 